\title{
Polyurethane foam (PUF) disk passive samplers derived polychlorinated biphenyls (PCBs) concentrations in the ambient air of Bursa-Turkey: Spatial and temporal variations and health risk assessment
}

\author{
Așkın Birgül a, Perihan Binnur Kurt-Karakus a, *, Henry Alegria ${ }^{b}$, Elif Gungormus c, \\ Halil Celik ${ }^{\mathrm{d}}$, Tugba Cicek ${ }^{\mathrm{c}}$, Emine Can Güven ${ }^{\mathrm{d}}$ \\ a Bursa Technical University, Department of Environmental Engineering, Faculty of Natural Sciences, Architecture and Engineering, Mimar Sinan Mahallesi \\ Mimar Sinan Bulvarı Eflak Caddesi No: 177, 16310, Ylldırım, Bursa, Turkey \\ ${ }^{\mathrm{b}}$ University of South Florida St Petersburg, Department of Environmental Science, Policy \& Geography, 140 7th Avenue South, St Petersburg, FL, 33701, USA \\ c Izmir Institute of Technology, Department of Chemical Engineering, Gülbahçe, Urla, 35430, Izmir, Turkey \\ d Akdeniz University, Faculty of Engineering, Department of Environmental Engineering, Dumlupinar Bulvarl, 07058, Konyaalt, Antalya, Turkey
}

\section{H I G H L I G H T S}

- Spatial and temporal variations of PCBs were monitored in ambient air of Bursa-Turkey using PUF disk passive samplers.

- A clear rural-agricultural-semi-urban-urban-industrial PCBs concentration gradient was observed.

- Principal component analysis (PCA) related possible sources and observed homologue group profiles.

- Calculated inhalation risk levels of PCBs at sampling sites did not pose serious adverse health effects.

\section{A R T I C L E I N F O}

\section{Article history:}

Received 17 September 2016

Received in revised form

16 November 2016

Accepted 25 November 2016

Handling Editor: Caroline Gaus

\section{Keywords:}

Polychlorinated biphenyls (PCBs)

Passive air samplers

Background to industrial transect

Health risk assessment

Bursa-Turkey

\begin{abstract}
A B S T R A C T
Polyurethane foam (PUF) passive samplers were employed to assess air concentrations of polychlorinated biphenyls (PCBs) in background, agricultural, semi-urban, urban and industrial sites in Bursa, Turkey. Samplers were deployed for approximately 2-month periods from February to December 2014 in five sampling campaign. Results showed a clear rural-agricultural-semi-urban-urban-industrial PCBs concentration gradient. Considering all sampling periods, ambient air concentrations of $\Sigma_{43} \mathrm{PCBs}$ ranged from 9.6 to $1240 \mathrm{pg} / \mathrm{m}^{3}$ at all sites with an average of $24.1 \pm 8.2,43.8 \pm 24.4,140 \pm 190,42.8 \pm 24.6$, $160 \pm 280,84.1 \pm 105,170 \pm 150$ and $280 \pm 540 \mathrm{pg} / \mathrm{m}^{3}$ for Mount Uludag, Uludag University Campus, Camlica, Bursa Technical University Osmangazi Campus, Hamitler, Agakoy, Kestel Organised Industrial District and Demirtas Organised Industrial District sampling sites, respectively. The ambient air PCB concentrations increased along a gradient from background to industrial areas by a factor of 1.7-11.4. 4Cl PCBs (31.50-81.60\%) was the most dominant homologue group at all sampling sites followed by 3-Cl, $7-\mathrm{Cl}, 6-\mathrm{Cl}$ and $5-\mathrm{Cl}$ homologue groups. Sampling locations and potential sources grouped in principal component analysis. Results of PCA plots highlighted a large variability of the PCB mixture in air, hence possible related sources, in Bursa area. Calculated inhalation risk levels in this study indicated no serious adverse health effects. This study is one of few efforts to characterize PCB composition in ambient air seasonally and spatially for urban and industrial areas of Turkey by using passive samplers as an alternative sampling method for concurrent monitoring at multiple sites.
\end{abstract}

(c) 2016 Elsevier Ltd. All rights reserved.

\footnotetext{
* Corresponding author.

E-mail address: perihan.kurt@btu.edu.tr (P.B. Kurt-Karakus).
}

\section{Introduction}

Polychlorinated biphenyls (PCBs) are a well-known class of ubiquitous pollutants in the environment. Owing to their chemical 
and thermal stability they have widely accumulated in soil, sediments and aquatic fauna, as well as being transported long distances in the atmosphere. From their first production in the 1930s, until their ban in the 1990s, approximately 1.3 million tons of PCBs have been produced, of which tens of thousands of tons are known to have been released into the environment, causing widespread pollution (Kim et al., 2011; Breivik et al., 2007). Typical sources of PCBs in the environment are past open/partially open and uncontrolled uses, past disposal activities, illegal disposal and accidental releases (Erickson, 2001).

International efforts, such as the Stockholm Convention on Persistent Organic Pollutants (POPs), enable coordination among countries for the phasing out of chemicals that remain in the environment for a long period of time and become widely distributed both in environmental media and in living organisms. The Stockholm Convention was adopted in 2001 and entered into force in 2004. In the case of Turkey, the decision to be a party was taken in the Grand National Assembly of Turkey in April 2009 (Official Gazette No: 27200) and accepted by the Council of Ministers in July 2009 (Official Gazette No: 27304). The legal procedure was completed as of January 2010 and Turkey is currently under the obligations of the Stockholm Convention. As is the case for many countries which are a part of the Stockholm Convention, PCBs were not produced in Turkey. Contrary to the $\mathrm{PCB}$ timeline over the world, the situation in Turkey is unclear.

Atmospheric monitoring for PCBs traditionally relies on high volume air samplers but the cost, dependence on electricity, and relative complexity of these samplers limits their use to sites with access to electricity and to monitoring networks with relatively few sites (Xiao et al., 2008). In recent years, various types of passive air samplers (PAS) have been developed and used for monitoring PCBs (Shoeib and Harner, 2002). Passive air samplers which absorb atmospheric PCBs on polyurethane foam (PUF) (Shoeib and Harner, 2002; Harner et al., 2004), semipermeable membrane (SPMD) (Bartkow et al., 2004), or XAD resins (Wania et al., 2003) have been developed in recent years as complementary tools for monitoring of atmospheric PCBs around the globe. Compared to conventional high volume air samplers, they are economical and do not require electricity. PASs can be deployed at many sites and for long periods (over several months) and, therefore, are suitable for investigating the spatial and temporal distributions of pollutants (MotelayMassei et al., 2005; Wang et al., 2010) and to assess their source receptor relationships (Baek et al., 2008). Passive air samplers have been successfully used in Asia (Jaward et al., 2005), Europe (Jaward et al., 2004), Turkey (Esen, 2013; Gaga et al., 2012; Lee et al., 2007) and other continental areas (Pozo et al., 2006; Gouin et al., 2005).

The analysis of pollutants in a PUF provides merely the amount sequestered in the PUF during the deployment period. Only after dividing the amount of chemicals (e.g., expressed in pg) by the corresponding air sampling volume (e.g., expressed in $\mathrm{m}^{3}$ ) is the concentration of POPs in air obtained (e.g., expressed in $\mathrm{pg} / \mathrm{m}^{3}$ ). The determination of the sampling volume requires extensive calibration exercises. Uptake rates of POPs (e.g., PCB) can vary from 2 to $8 \mathrm{~m}^{3} /$ day (Shoeib and Harner, 2002) and typically lie between 3 and $4 \mathrm{~m}^{3}$ /day (Klánová et al., 2008; Pozo et al., 2006, 2009; Shoeib and Harner, 2002).

Since concentrations of PCBs are reported at higher concentrations in some animals, dietary PCBs exposure (especially consumption of contaminated fish) has historically been ranked in significance over dermal and inhalation exposure (Humphrey, 1983; Chiu et al., 2004). Although many studies clearly show that diet is a dominant exposure source for many individuals, in some cases airborne PCBs from new/recent sources and legacy sources may lead to inhalation exposure at levels comparable and even sometimes higher than dietary exposure to these chemicals
(Ampleman et al., 2015; Currado and Harrad, 1998; Norström et al., 2010). Studies on PCB congener patterns in human serum showed indications of exposure to PCBs of atmospheric origin (DeCaprio et al., 2005), indicating that dermal and inhalation exposure cannot be always neglected.

Bursa city, with a population over 2.5 million has 13 large industrial zones (including Turkey's first industrial zone) in addition to 19 small-scale industrial zones, one free-trade zone and also a technology development center which provides services to industry. In Bursa, home to Turkey's second largest Export Union, production has been focused on the textile, automotive, automotive spare parts, ready-to-wear garments, machinery and metal industries, dry-fresh and frozen foods, agriculture and service sectors. The high population growth and rapid industrialization and urbanization during the last decades have resulted in significant environmental problems, including severe PCB contamination (Tasdemir et al., 2012; Birgul and Tasdemir, 2011, 2012; Salihoglu and Tasdemir, 2009). To determine ambient air quality of Bursa Metropolitan City with regards to POPs, a few studies were conducted using active high volume air samplers. However, these studies were limited to one or two locations to measure the seasonality of contaminants at these sites. There have been no studies to measure concentrations of semi-volatile organic compounds simultaneously at multiple sampling sites to investigate spatial variations as well as temporal changes. There are studies where passive samplers were employed to monitor PCBs and other POPs in ambient air in industrial/urban sites such as Aliaga (Aydin et al. 2014; Kaya et al., 2012; Odabasi et al., 2015) and Iskenderun (Odabasi et al., 2016) in Turkey. However, to our knowledge, this study is the first report on the employment of PUF disk based passive air samplers at multiple locations for simultaneous monitoring of PCBs in Bursa.

The aim of this study was to exploit the advantages of passive sampling (1) to determine atmospheric concentrations of PCBs at the eight different sampling sites in Bursa, (2) to examine spatial and seasonal variations of PCBs, and (3) to identify the possible sources of atmospheric PCBs in the study area.

\section{Materials and methods}

\subsection{Study area and sampling program}

The target compounds in ambient air were monitored at 8 sites. These were one rural site (Mount Uludag (\#1, MU)), two urban sites (Bursa Technical University Osmangazi Campus (\#2, BTU) and Hamitler Area (\#3, HMT)), two semiurban sites (Uludag University Campus (\#4, UUC) and Camlica Area (\#5, CAM)), two industrial sites (Kestel Organised Industrial District (\#6, KOID) and Demirtas Organised Industrial District (\#7, DOID)) and an agricultural site (Ağaköy Village (\#8, AGK)) (Fig. 1). Five sampling campaigns were carried out between February and December 2014. During the sampling campaigns, average ambient temperature was between range of $9.2{ }^{\circ} \mathrm{C}$ and $24^{\circ} \mathrm{C}$, at the sampling stations depending on the sampling period.

\subsection{Chemicals and reagents}

All chromatography-grade solvents, anhydrous sodium sulfate (granulated for trace organic analysis), and neutral alumina (90 active neutral, $0.063-0.2 \mathrm{~mm}$ particulate size) were purchased from Merck (Merck EMD Millipore, USA). ${ }^{13} \mathrm{C}_{12}$-labelled PCB congener mixture (PCB-28, -52, -101, -138, -153, -180 and -209) was purchased from Cambridge Isotope Laboratories (MA, USA). A mixture of 45 PCB congeners (Protocol Analytical LLC, New Jersey, USA) (PCB -18, -22, -28, -31, -41/64, -44, 49, -52, -54, -56, -60, -70, 


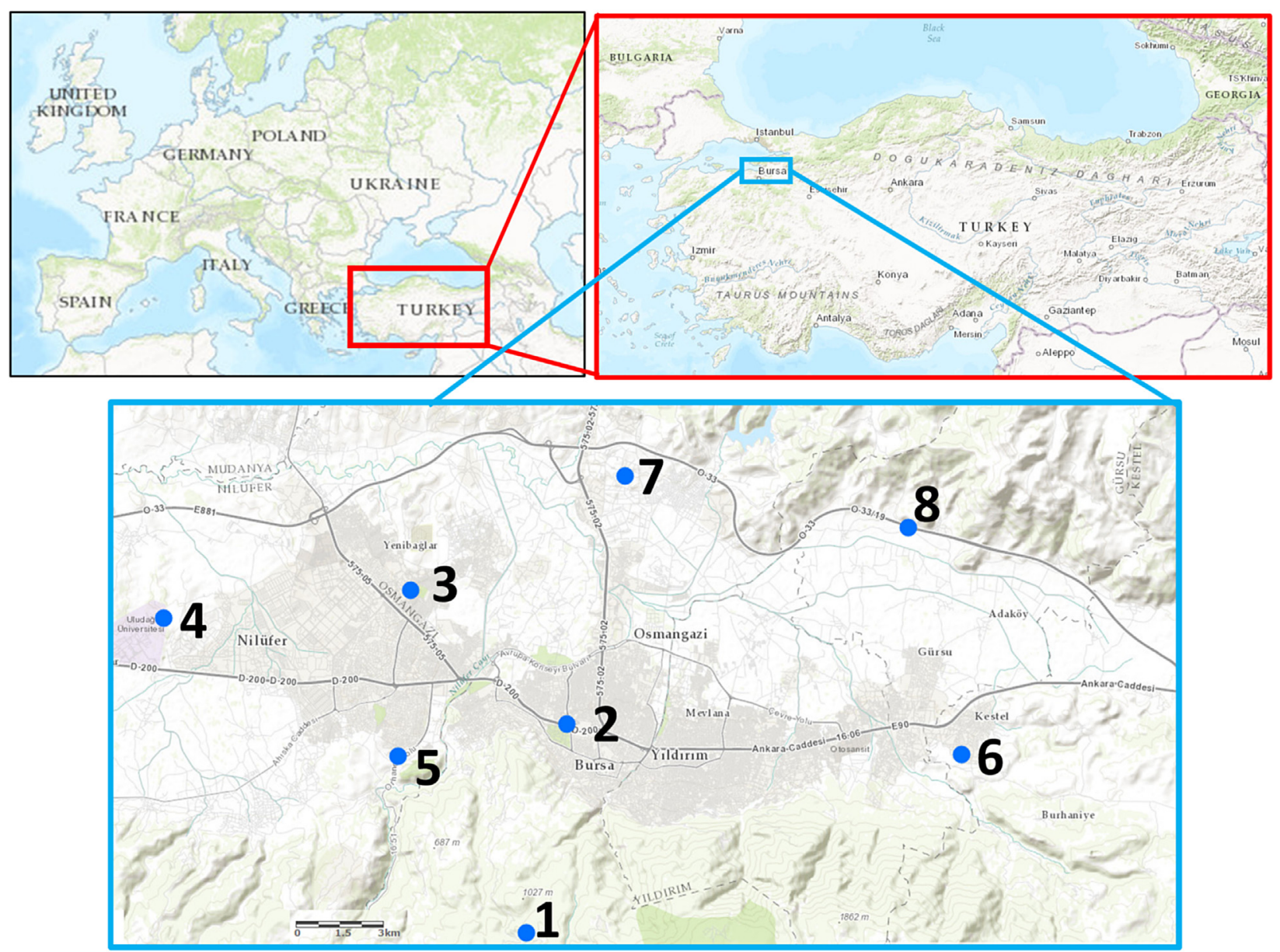

Fig. 1. Sampling sites.

$-74,-87,-90 / 101,-95,-99,-104,-105,-110,-114,-118,-123,-132$, $-138,-141,-149,-151,-153,-156,-157,-158,-167,-170,-174,-180$, $-183,-187,-188,-189,-194,-199$ and -203$)$ was from Protocol Analytical LLC (New Jersey, USA). Individual solutions of PCB-34, -62 and -204 were purchased from Accustandard (CT, USA). All stock solutions and calibration solutions were prepared in isooctane (Puriss p.a. $\geq 99.5 \%$ (GC), Sigma Aldrich, MO, USA). SPE cartridges (Supelco Supelclean ENVI Florisil SPE Tubes with Teflon Frits. $3 \mathrm{~mL} 500 \mathrm{mg}$ ) were from Sigma Aldrich (MO, USA).

\subsection{Analytical procedure}

\subsubsection{Sampler preparation and deployment}

In order to remove any probable organic residues completely, all equipment used for the analysis in the laboratory was rinsed with solvent before their first usage. Before being used in the air sampling, PUF disks (14 cm diameter; $1.35 \mathrm{~cm}$ thick; surface area, $365 \mathrm{~cm}^{2}$; mass, $4.40 \mathrm{~g}$; volume, $207 \mathrm{~cm}^{3}$; density, $0.0213 \mathrm{~g} / \mathrm{cm}^{3}$; Tisch Environmental, Cleaves Ohio, USA) were soaked in warm tap water overnight followed by a soaking period of $4 \mathrm{~h}$ in distilled water. After removal of excess water by hand squeezing, they were subject to Soxhlet extraction using acetone (ACE), acetone:hexane mixture (ACE:HEX 1:1 v/v) and hexane (HEX) for at least $18 \mathrm{~h}$ each in sequence. Then, they were dried in a desiccator under vacuum and wrapped in aluminum foil, preserved in sealed plastic bags and kept in the freezer until deployment for sampling.

PUF disks were spiked with a depuration mixture consisting of three PCB congeners (PCB-34, 62 and 204) at least 3 days prior to deployment. Spiked PUFs were wrapped with aluminum foil, placed in solvent-cleaned tin cans having Teflon-lined lips, and stored in the refrigerator until deployment to the sampling locations. Passive air samples were collected using apparatus designed by Shoeib and Harner (2002) and Harner et al. (2004) and used in other field investigations (Gouin et al., 2005; Jaward et al., 2004; Motelay-Massei et al., 2005; Pozo et al., 2004; Wang et al., 2009, 2010). PUF disks were suspended inside two stainless steel bowls, the upper inverted one being slightly larger to allow airflow between the two bowls. Samplers were exposed for 43-75 days (Table 1). Three field blanks in each sampling period were exposed to air about $10 \mathrm{~s}$ at the selected sampling points and then analyzed as a regular sample. When the sampling was finished, the PUF disks were transferred to laboratory and stored at $-4{ }^{\circ} \mathrm{C}$ until analysis.

\subsubsection{Extraction}

A mixture of ${ }^{13} \mathrm{C}_{12} \mathrm{PCB}-28,-52,-101,-138,-153,-180$ and 209 (5 ng each) was added to PUF disks before extraction. The PUF disks were subjected to Soxhlet extraction for $18 \mathrm{~h}$ using approx. $250 \mathrm{~mL}$ of $1: 1(\mathrm{v} / \mathrm{v})$ HEX:ACE mixture. The volume of extract was reduced to $5 \mathrm{~mL}$ by using a rotary evaporator and then to $1 \mathrm{~mL}$ under a gentle nitrogen gas stream. The extracts were cleaned up for PCBs using Florisil SPE cartridges. The cartridge was cleaned with $8 \mathrm{~mL}$ methanol followed by $4 \mathrm{~mL}$ hexane, the sample was added in a $1 \mathrm{~mL}$ volume and the cartridge was eluted with $8 \mathrm{~mL}$ hexane followed by $10 \mathrm{~mL}$ ethyl acetate. Extracts were combined, reduced to $1 \mathrm{~mL}$ and transferred to isooctane by nitrogen blow-down, and $50 \mathrm{ng}$ of ${ }^{13} \mathrm{C}_{12}$ PCB- 105 was added as an internal standard. 
Table 1

Air concentrations of $\Sigma_{43}$ PCBs in rural, agricultural, semi-urban, urban and industrial sites in Bursa and comparison from diverse PAS-PUF sampling studies.

\begin{tabular}{|c|c|c|c|c|c|c|c|}
\hline & $\begin{array}{l}\text { Number of }>\mathrm{MDL} \\
\text { congeners }\end{array}$ & $\begin{array}{l}\text { Sampling duration } \\
\text { (Days) }\end{array}$ & $\begin{array}{l}\text { Sampling rate ( } \mathrm{R}, \\
\mathrm{m}^{3} / \text { day) }\end{array}$ & $\begin{array}{l}\text { Range (Individual } \\
\text { congeners) } / \Sigma_{43} \mathrm{PCBs}\end{array}$ & $\begin{array}{l}\text { Site avg } \pm \text { SD of } \Sigma_{43} \text { PCBs } \\
\text { (Range) }\end{array}$ & $\begin{array}{l}\text { Median of } \\
\Sigma_{43} \text { PCBs }\end{array}$ & $\begin{array}{l}\text { GM of } \\
\Sigma_{43} \text { PCBs }\end{array}$ \\
\hline \multicolumn{8}{|c|}{ Site: MU (Type: Rural) } \\
\hline $\begin{array}{l}\text { February-April } \\
2014\end{array}$ & 4 & 67 & 9.06 & $3.30-11.2 / 22.80$ & $24.1 \pm 8.20(12.6-35.5)$ & 23.4 & 22.9 \\
\hline April-June 2014 & 6 & 63 & 7.57 & $3.4-13.3 / 35.5$ & & & \\
\hline June-August 2014 & 3 & 68 & 5.01 & $3.50-5.30 / 12.60$ & & & \\
\hline $\begin{array}{l}\text { August-October } \\
2014\end{array}$ & 3 & 66 & 3.33 & $3.70-15.3 / 23.40$ & & & \\
\hline $\begin{array}{l}\text { October } \\
\text {-December } \\
2014\end{array}$ & 3 & 51 & 5.72 & $4.12-14.6 / 26.30$ & & & \\
\hline \multicolumn{8}{|c|}{ Site: UUC (Type: Semiurban) } \\
\hline $\begin{array}{l}\text { February-April } \\
2014\end{array}$ & 13 & 66 & 5.08 & $2.80-18.0 / 80$ & $43.8 \pm 24.4(15.6-80)$ & 45.4 & 38.1 \\
\hline April-June 2014 & 7 & 61 & 7.64 & $3.10-14.6 / 45$ & & & \\
\hline June-August 2014 & 3 & 71 & 5.08 & $3.10-8.80 / 15.60$ & & & \\
\hline $\begin{array}{l}\text { August-October } \\
2014\end{array}$ & 8 & 64 & 5.03 & $2.30-11.5 / 50$ & & & \\
\hline $\begin{array}{l}\text { October } \\
\text { - December } \\
2014\end{array}$ & 3 & 44 & 6.63 & $3.60-18.9 / 28.60$ & & & \\
\hline \multicolumn{8}{|c|}{ Site: CAM (Type: Semiurban) } \\
\hline $\begin{array}{l}\text { February-April } \\
2014\end{array}$ & 25 & 67 & 5.98 & $3.70-10.7 / 146$ & $180 \pm 210(<$ MDL-480 $)$ & 95.5 & 110 \\
\hline April-June 2014 & 5 & 63 & 7.79 & $3.50-14.9 / 45.30$ & & & \\
\hline June-August 2014 & 9 & 68 & 3.63 & $3.60-160 / 480$ & & & \\
\hline $\begin{array}{l}\text { August-October } \\
2014\end{array}$ & 0 & 66 & 6.08 & $<\mathrm{MDL}$ & & & \\
\hline $\begin{array}{l}\text { October } \\
\text {-December } \\
2014\end{array}$ & 5 & 51 & 7.44 & $3.40-16.4 / 44.20$ & & & \\
\hline \multicolumn{8}{|c|}{ Site: BTU (Type: Urban) } \\
\hline $\begin{array}{l}\text { February-April } \\
2014\end{array}$ & 7 & 67 & 6.25 & $3.90-21.1 / 62.80$ & $\begin{array}{l}42.90 \pm 24.60(19.6 \\
-74.1)\end{array}$ & 36.7 & 37.2 \\
\hline April-June 2014 & 3 & 63 & 5.92 & $5.60-9.60 / 21.30$ & & & \\
\hline June-August 2014 & 5 & 68 & 11.2 & $2.80-13.4 / 36.70$ & & & \\
\hline $\begin{array}{l}\text { August-October } \\
2014\end{array}$ & 4 & 66 & 3.77 & $2.60-9.50 / 19.60$ & & & \\
\hline $\begin{array}{l}\text { October } \\
\text {-December } \\
2014\end{array}$ & 4 & 51 & 6.13 & $7.10-32.5 / 74.10$ & & & \\
\hline \multicolumn{8}{|c|}{ Site: HMT (Type: Urban) } \\
\hline $\begin{array}{l}\text { February-April } \\
\quad 2014\end{array}$ & 7 & 67 & 5.50 & $6.40-600 / 660$ & $160 \pm 280(21.2-660)$ & 31.6 & 60.0 \\
\hline April-June 2014 & 4 & 63 & 8.03 & $4.00-12.4 / 27.80$ & & & \\
\hline June-August 2014 & 3 & 68 & 4.35 & $3.80-13.1 / 21.20$ & & & \\
\hline $\begin{array}{l}\text { August-October } \\
2014\end{array}$ & 8 & 66 & 7.19 & $2.80-16.9 / 58.90$ & & & \\
\hline $\begin{array}{l}\text { October } \\
\text {-December } \\
2014\end{array}$ & 4 & 51 & 5.69 & $4.04-11.5 / 31.60$ & & & \\
\hline \multicolumn{8}{|c|}{ Site: AGK (Type: Agricultural) } \\
\hline $\begin{array}{l}\text { February-April } \\
2014\end{array}$ & 7 & 66 & 4.39 & $4.30-197 / 248$ & $84.2 \pm 105(9.6-248)$ & 22.7 & 37 \\
\hline April-June 2014 & 3 & 62 & 5.33 & $2.50-15.9 / 22.7$ & & & \\
\hline June-August 2014 & 3 & 70 & 7.53 & $2.16-4.42 / 9.84$ & & & \\
\hline $\begin{array}{l}\text { August-October } \\
2014\end{array}$ & 2 & 66 & 5.05 & $3.86-127 / 131$ & & & \\
\hline $\begin{array}{l}\text { October } \\
\text {-December } \\
2014\end{array}$ & 2 & 51 & 6.31 & $4.36-5.24 / 9.60$ & & & \\
\hline \multicolumn{8}{|c|}{ Site: KOID (Type: Industrial) } \\
\hline $\begin{array}{l}\text { February-April } \\
2014\end{array}$ & 11 & 63 & 11.1 & $3.50-25.1 / 118$ & $170 \pm 150(21-340)$ & 120 & 110 \\
\hline April-June 2014 & 4 & 61 & 6.26 & $4.10-320 / 340$ & & & \\
\hline June-August 2014 & 7 & 65 & 5.15 & $3.0-290 / 320$ & & & \\
\hline $\begin{array}{l}\text { August-October } \\
2014\end{array}$ & 4 & 65 & 5.78 & $3.60-9.40 / 21$ & & & \\
\hline $\begin{array}{l}\text { October } \\
\text {-December } \\
2014\end{array}$ & 6 & 62 & 5.41 & $3.30-20.1 / 58$ & & & \\
\hline
\end{tabular}


Table 1 (continued)

\begin{tabular}{|c|c|c|c|c|c|c|c|}
\hline & $\begin{array}{l}\text { Number of }>\text { MDL } \\
\text { congeners }\end{array}$ & $\begin{array}{l}\text { Sampling duration } \\
\text { (Days) }\end{array}$ & $\begin{array}{l}\text { Sampling rate }(\mathrm{R}, \\
\left.\mathrm{m}^{3} / \text { day }\right)\end{array}$ & $\begin{array}{l}\text { Range (Individual } \\
\text { congeners) } / \Sigma_{43} \mathrm{PCBs}\end{array}$ & $\begin{array}{l}\text { Site avg } \pm \text { SD of } \Sigma_{43} \text { PCBs } \\
\text { (Range) }\end{array}$ & $\begin{array}{l}\text { Median of } \\
\Sigma_{43} \text { PCBs }\end{array}$ & $\begin{array}{l}\mathrm{GM} \text { of } \\
\Sigma_{43} \mathrm{PCBs}\end{array}$ \\
\hline \multicolumn{8}{|c|}{ Site: DOID (Type: Industrial) } \\
\hline $\begin{array}{l}\text { February-April } \\
\quad 2014\end{array}$ & 15 & 66 & 5.66 & $4.10-490 / 1240$ & $280 \pm 540(22.9-1240)$ & 40.9 & 71.6 \\
\hline April-June 2014 & 2 & 62 & 5.64 & $5.76-17.1 / 22.9$ & & & \\
\hline June-August 2014 & 4 & 70 & 6.38 & $3.20-18.2 / 40.9$ & & & \\
\hline $\begin{array}{l}\text { August-October } \\
\qquad 2014\end{array}$ & 4 & 66 & 5.77 & $3.70-14.7 / 36.6$ & & & \\
\hline $\begin{array}{l}\text { October } \\
\text {-December } \\
2014\end{array}$ & 4 & 51 & 7.56 & $3.60-24.0 / 44.4$ & & & \\
\hline Region & Sampling Site Type & Sites $(\mathbf{N})$ & Congeners & $\operatorname{Avg}\left(p g / m^{3}\right)$ & Range (pg/m $\left.{ }^{3}\right)$ & \multicolumn{2}{|l|}{ Reference } \\
\hline Argentina & Rural & $7(31)$ & $\Sigma 42$ & 10 & BDL-35 & \multirow{2}{*}{\multicolumn{2}{|c|}{$\begin{array}{l}\text { Astoviza et al. (2016) } \\
\text { Motelay-Massei et al. } \\
(2005)\end{array}$}} \\
\hline Canada & Rural & $1(3)$ & $\Sigma 13$ & 152 & $66-239$ & & \\
\hline Japan & Rural & $37(37)$ & $\Sigma 142$ & 322 & $41-7279$ & \multicolumn{2}{|c|}{ Hogarh et al. (2012) } \\
\hline Turkey & Rural & $1(5)$ & $\Sigma 43$ & 24.1 & $12.60-35.50$ & \multicolumn{2}{|l|}{ This Study } \\
\hline Argentina & Suburban/semirural & $3(13)$ & $\Sigma 42$ & 48 & $3-146$ & \multicolumn{2}{|c|}{ Astoviza et al. (2016) } \\
\hline Canada & Suburban/semirural & $2(5)$ & $\Sigma 13$ & 96 & $67-129$ & \multicolumn{2}{|c|}{$\begin{array}{l}\text { Motelay-Massei et al. } \\
\text { (2005) }\end{array}$} \\
\hline Japan & Suburban/semirural & $4(4)$ & $\Sigma 142$ & 291 & $59-696$ & \multicolumn{2}{|c|}{ Hogarh et al. (2012) } \\
\hline Turkey & Suburban/semirural & $2(10)$ & $\Sigma 43$ & 104 & $<$ MDL-480 & \multicolumn{2}{|l|}{ This study } \\
\hline Spain & Urban & $6(6)$ & $\Sigma 21$ & 117 & $33-259$ & \multicolumn{2}{|c|}{ Pozo et al. (2009) } \\
\hline Argentina & Urban & 15 & $\Sigma 42$ & 146 & $2-937$ & \multicolumn{2}{|c|}{ Astoviza et al. (2016) } \\
\hline India & Urban & $1(8)$ & $\Sigma 48$ & 278 & $133-390$ & \multicolumn{2}{|c|}{ Pozo et al. (2011) } \\
\hline Turkey & Urban & $2(10)$ & $\Sigma 43$ & 100 & 19.60-660 & \multicolumn{2}{|l|}{ This study } \\
\hline Chile & Industrial & $6(6)$ & $\Sigma 48$ & 160 & $40-350$ & \multicolumn{2}{|c|}{ Pozo et al. (2012) } \\
\hline Turkey & Industrial & $2(10)$ & $\Sigma 43$ & 223 & $21-1240$ & \multicolumn{2}{|l|}{ This study } \\
\hline
\end{tabular}

\subsubsection{Instrumental analysis}

Analysis of PCBs congeners was conducted on a GC (Agilent 7890B) coupled with an MSD (Agilent 5977 MSD) operated on EI (electron impact)-selective ion monitoring (SIM) mode. Separation of congeners was performed on a capillary DB-5 column $(60 \mathrm{~m}$, $0.25 \mathrm{~mm}$ i.d., $0.25 \mu \mathrm{m}$ film thickness, J\&W Scientific) (coeluting congeners (PCB-41/64 and PCB-90/101) were quantified together. Sample volumes of $2 \mu \mathrm{L}$ were injected splitless (split opened after $1.25 \mathrm{~min})$. Helium was used as carrier gas ( $1.1 \mathrm{~mL} / \mathrm{min})$. Injector, ion source $(70 \mathrm{eV})$, quadrupole, and auxiliary were operated at $200^{\circ} \mathrm{C}$, $230{ }^{\circ} \mathrm{C}, 150^{\circ} \mathrm{C}$, and $310^{\circ} \mathrm{C}$, respectively. Temperature program for PCBs was $1 \mathrm{~min}$ at $90^{\circ} \mathrm{C}, 15^{\circ} \mathrm{C} / \mathrm{min}$ to $160^{\circ} \mathrm{C}, 3^{\circ} \mathrm{C} / \mathrm{min}$ to $210^{\circ} \mathrm{C}$, and $10{ }^{\circ} \mathrm{C} / \mathrm{min}$ to $310^{\circ} \mathrm{C}$ (wait $10 \mathrm{~min}$ ).

\subsubsection{Deriving air concentrations based on estimated air volumes}

Concentrations of target congeners in air were derived from the chemical amount accumulated in PUF disk ( $\mathrm{ng} /$ sampler) divided by the effective air volume $\left(\mathrm{V}_{\mathrm{AIR}}, \mathrm{m}^{3}\right)$. Site-specific effective air volume $\left(V_{\text {AIR }}\right)$ which is based on site-specific linear phase sampling rates $\left(R_{\text {sampling }}=\mathrm{m}^{3} /\right.$ day $)$ was calculated using the equation proposed by Shoeib and Harner (2002). Details on the derivation air volumes based on the loss of depuration compounds are given elsewhere (Pozo et al., 2004; Gouin et al., 2005). GAPS template (Harner, 2016; Parnis et al., 2016) was used for calculations. Resulting $\mathrm{V}_{\mathrm{AIR}}$ and Rvalues are summarized in Table S1 (see Supporting Information) for PCBs. $R$ values ranged from 3.33 to $11.15 \mathrm{~m}^{3} / \mathrm{d}$ with a mean of $6.21 \pm 1.69 \mathrm{~m}^{3} / \mathrm{d}$, which is similar to those reported by Gouin et al. (2005), $3.1 \mathrm{~m}^{3} / \mathrm{d}$, for samplers deployed in Eastern Canada and $4.78 \pm 2.3 \mathrm{~m}^{3} / \mathrm{d}$ by Pozo et al. (2004) for samplers deployed in Chile.

\subsection{Quality control $(Q C) /$ quality assurance $(Q A)$}

The quality of analytical procedures was checked via recoveries and reproducibility. Method recovery efficiencies (\%) of ${ }^{13} \mathrm{C}_{12} \mathrm{PCB}-$ $28,-52,-101,-138,-153,-180$ and 209 ( 5 ng each) were found as follows: $89.5 \pm 15.0,100 \pm 17.6,90.2 \pm 14.0,87.7 \pm 14.9,105 \pm 19.9$, $96.2 \pm 14.9$ and $92.6 \pm 14.5$, respectively. Blank levels were assessed through field (clean PUF disc was exposed to air in the field for approx. $10 \mathrm{~s}, \mathrm{n}=5$ ) and laboratory (clean PUF disc, $\mathrm{n}=10$ ) blanks. Instrumental detection limits (IDLs) were estimated by injecting low concentrations of target analytes until a small peak at $\sim 3: 1$ signal:noise ratio was obtained. These IDLs are expressed in $\mathrm{pg} / \mathrm{m}^{3}$ air and calculation was done assuming extract volumes of $1.0 \mathrm{~mL}$ and $350 \mathrm{~m}^{3}$ air. Method detection limits (MDL) in air samples were defined as the average blank (by combining field and laboratory blanks, $n=15$ ) plus three standard deviations (SD). Sample amounts were compared to MDLs and IDLs and if a peak was observed for a sample constituent but the quantity was $<\mathrm{MDL}, 1 / 2$ of IDL was used for statistical purposes. Peaks were only integrated if the signal to noise ratio was $\sim 3: 1$, otherwise, they were considered not detected. Target congeners were not detected in blank samples except PCB-54. The MDL value for all target congeners was $0.30 \mathrm{pg} /$ $\mathrm{m}^{3}$ except for PCB-54 whose MDL value was $3.0 \mathrm{pg} / \mathrm{m}^{3}$. The concentration values for PCB-54 was corrected with blanks in order to eliminate the background contamination and artifacts by subtracting its average blank concentration from concentration of congener in the sample.

\section{Results and discussion}

\subsection{Ambient air concentrations}

A summary of data of ambient air concentrations is presented in Table 1. Considering all sampling periods, the atmospheric concentrations of $\Sigma_{43}$ PCBs ranged from 9.6 to $1240 \mathrm{pg} / \mathrm{m}^{3}$ with an average of $24.1 \pm 8.2,43.8 \pm 24.4,140 \pm 190,42.8 \pm 24.6,160 \pm 280$, 
$84.1 \pm 105,170 \pm 150$ and $280 \pm 540 \mathrm{pg} / \mathrm{m}^{3}$ for MU, UUC, CAM, BTU, HMT, AGK, KOID and DOID sampling sites, respectively.

PCBs were used intensively in Turkey, mainly in electrical equipment such as transformers. It is reported in the updated version of National Implementation Plan (NIP, 2015) of Turkey on POPs that there is a total of 1080 tonnes of pure PCBs containing materials and equipment present in the country. However, it should be noted that this figure was only reached based on answers of the surveys listing PCB-contaminated equipment with other equipment and site visits made in September 2013. There might be PCBs or PCBs-contaminated equipment in the facilities that did not answer the surveys. Additionally, many items of PCBs by use category including semi closed/open applications (e.g. hydraulic, lubricant, plastic, sealant, printing ink) have the potential to contain small amounts of PCBs. It is well known that sources of PCBs in urban areas include off-gassing from PCB-treated construction material and leakage from closed systems such as older electrical equipment (Breivik et al., 2007).

Turkey signed and executed the Stockholm Convention in 2001 and became a State Party to the Convention in 2010 (MoEU, 2016). Therefore, use of PCBs has been prohibited in Turkey. Turkish Legislation on Control of Air Pollution Originating from Industrial Activities (Official Gazzette, 2013) sets a limit value of $<0.1 \mathrm{ng} / \mathrm{Nm}^{3}$ $\left(\mathrm{Nm}^{3}=\right.$ volume of $1 \mathrm{~m}^{3}$ of air under normal conditions of pressure $(101.330 \mathrm{kPa})$ and temperature $(273 \mathrm{~K}))$ to control air pollution originating from emissions of industrial activities. Results of the current study shows that ambient air concentration values determined in Bursa metropolitan city are lower than the legal limits. However, considering the potential carcinogenic properties of these pollutants, they still may constitute a risk for the human and environmental health in the area.

Fig. 2 presents the annual average total concentration values of the PCBs at each sampling site. As is seen from the figure, the ambient air PCB concentrations are increasing along a gradient from background to industrial areas by a factor of 1.7-11.4. A clear 5-10 fold increase along a rural to urban (Harner et al., 2004; Motelay-Massei et al., 2005) and an increase by a factor of 2-5 along a rural to industrial (Pozo et al., 2012) transect have been reported in previous research. Increase in air concentrations at sites follow the trend: MU $<$ UUC < BTU < AGK < CAM < HMT < KOID < DOID. Greater concentrations at industrial sites points to the role of industrial areas in Bursa as potential sources of such pollutants. Research in other parts of the world have also reported the role of industrial (Pozo et al., 2012) and urban areas (Motelay-Massei et al., 2005; Persoon et al., 2010) as sources of PCBs 3- to 5-Cl homologue groups represented between $61 \%$ and $99 \%$ of total PCB amount in the atmosphere of Bursa. The contribution of some homologue groups had a quite similar variation throughout sampling campaign. The more volatile 3-, 4- and 5- $\mathrm{Cl}$ congeners were most

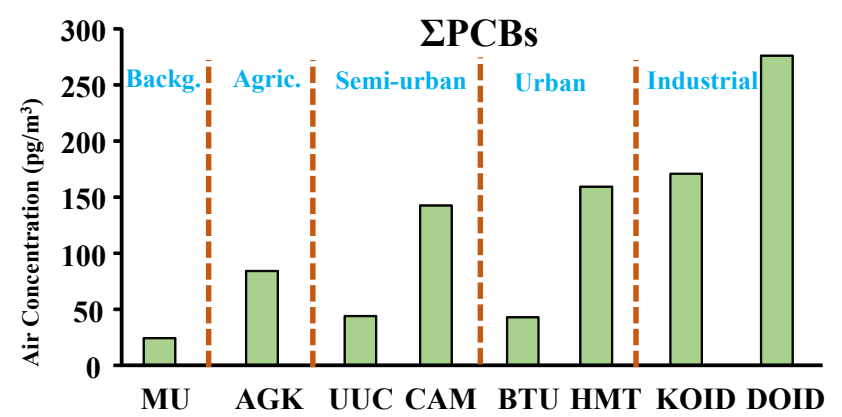

Fig. 2. Annual average air concentrations of $\Sigma_{43}$ PCBs across sampling sites in Bursa. abundant from February to April, accounting for $50-60 \%$ of the total amount of PCBs in the Bursa atmosphere. In contrast, the contribution of 6-, 7- and $8-\mathrm{Cl}$ congeners was at the minimum during the sampling campaign. It is worth noting that PUF-disk sampler collects mainly gas-phase chemicals via diffusion and therefore this may be the reason why heavier PCBs were at the minimum in the current study. However, although such a disadvantage of passive samplers, they are still useful to have a quick snap shot of semi-volatile organics concentrations in air at multiple sites concurrently for a given area.

In this study, all sites showed similar patterns of PCBs homologue groups. The PCB profile at all sampling sites was dominated by $4-\mathrm{Cl}$ PCBs (31.5-81.6\%). 3-Cl PCBs were the second dominant homologue group followed by $7-\mathrm{Cl}, 6-\mathrm{Cl}$ and $5-\mathrm{Cl}$ homologue groups. Dominance of 3-Cl and 4-Cl PCBs was observed in industrial, rural and urban (Zhang et al., 2008) areas in other parts of the world. On the other hand, Pozo et al. (2012) reported dominance of $5-\mathrm{Cl}$ to $7-\mathrm{Cl}$ homologue groups in air samples in industrial areas of Chile. In a study conducted by Kaya et al. (2012), low molecular weight congeners (3- and 4-Cl) dominated the $\Sigma_{41} \mathrm{PCB}$ concentrations in Aliaga industrial region in Turkey. Bozlaker et al. (2008) also reported dominance of $3-\mathrm{Cl}$ to $5-\mathrm{Cl} \mathrm{PCBs}$ in Aliaga industrial region of the country. Cindoruk and Tasdemir (2007) reported that PCBs were often found as 3-Cl and 4-Cl (65.7\% and 25.1\%) for BOID (Bursa Organised Industrial District) site of Bursa, while 5-Cl, 6-Cl and 7-Cl PCBs were at low levels. Esen (2013) reported higher percent contribution of 7-Cl PCBs in Bursa compared to values reported by Cindoruk and Tasdemir (2007).

In general, the concentration of the congeners decreased with the increasing number of chlorine atoms. Based on the results of the current study, we suggest that the main factors controlling congener composition of PCBs in our sampling areas are local sources such as coal combustion, sintering (i.e. cement clinker), waste disposal/waste incineration (EEA, 2005) rather than long range atmospheric transport which was for the case for Izmir (Mulder et al., 2015), which is another industrial city in the west coast of Turkey. Results of temporal variability plot (Fig. 3) also supports this hypothesis. Birgul and Tasdemir (2012) conducted a study to determine the effect of different factors on the deposition fluxes of the polychlorinated biphenyls measured at an urban site namely Yavuzselim which is located in Ylldırım district of Bursa. They reported that 5- $\mathrm{Cl}, 6-\mathrm{Cl}$, and 8-Cl PCBs had higher deposition velocity in rainy periods while $7-\mathrm{Cl}$ and $8-\mathrm{Cl}$ PCBs were more dominant in dry periods. In addition, different parameters such as sampler type, atmospheric concentrations, meteorological parameters, sampling site characteristics, and sampling periods had effects on deposition mechanisms of the PCBs.

\subsection{Temporal and spatial variability}

Temporal variations of PCBs concentration and ambient average temperature at each sampling site are shown in Fig. 3. $\Sigma_{43}$ PCBs generally showed a uniform distribution in different sampling seasons at AGK and UUC. HMT and DOID also showed a uniform distribution of $\Sigma_{43}$ PCBs except for February-April period where a spring pulse has been observed. MU showed pulses in concentration of $\Sigma_{43} \mathrm{PCBs}$ in February-April and in August-October. KOID and CAM showed a clear temperature dependent gradient, probably due to air-surface exchange. A PCB concentration peak in the air in spring has been reported by Backe et al. (2000) and Gouin et al. (2005). This spring pulse was attributed to the rising temperature that causes volatilization of compounds that have deposited to surfaces during the colder months. It may favor lighter congeners as they are more likely to have approached equilibrium between the air and top litter layer material. If passive samplers 


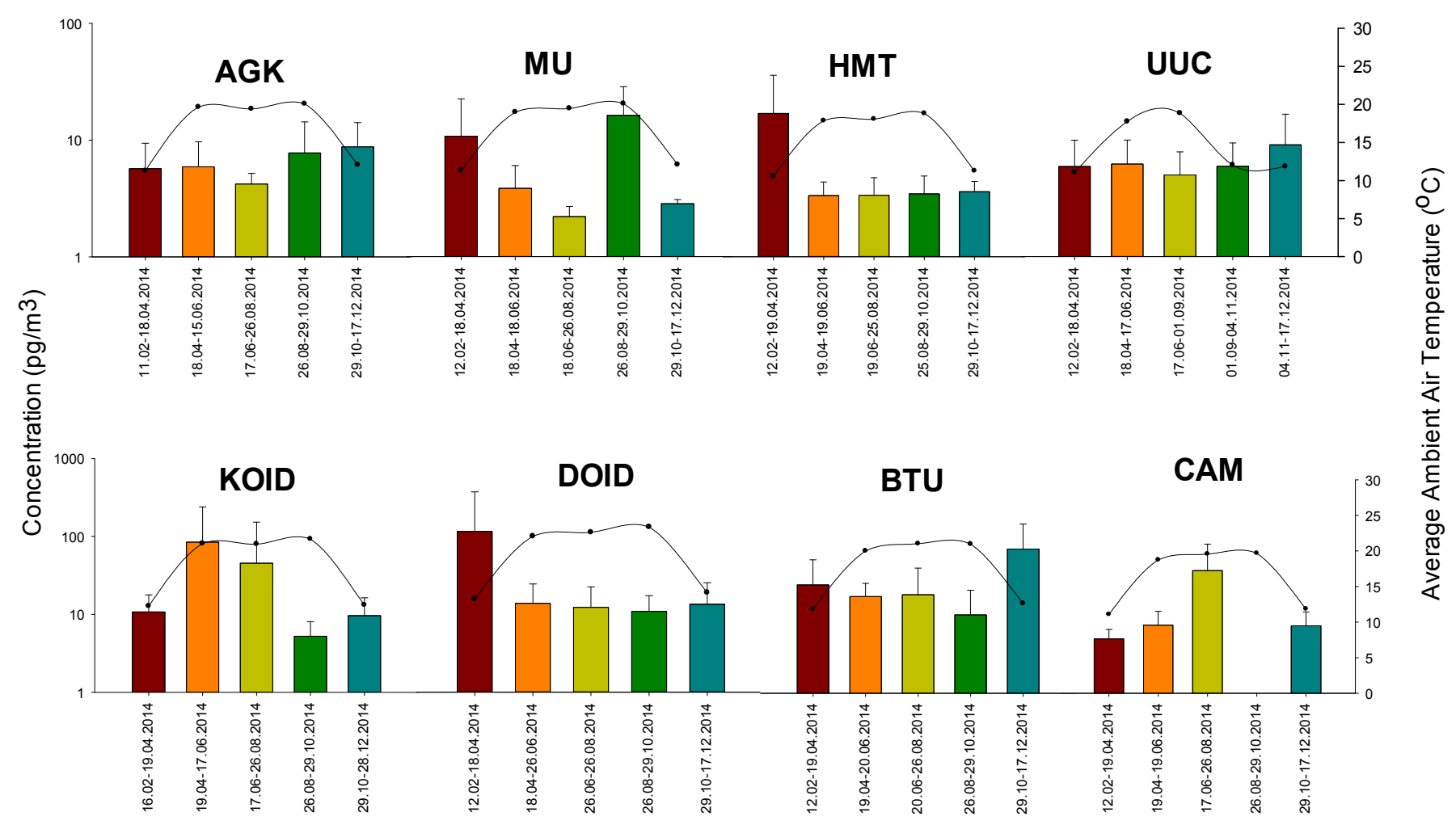

Date

Fig. 3. Temporal variations of the $\mathrm{PCB}$ concentration values (line above the bars represent average ambient temperature).

approach equilibrium for lighter compounds at the end of the sampling period, compounds taken up earlier may re-volatilize from the sampler when burdens in the air decrease after such a pulse. Different factors such as sampling site characteristics, meteorological conditions, local sources and atmospheric transportation mechanisms might effect measured concentration values.

It is well known that fresh emissions from technical mixtures of commercial PCBs are enriched in the heavier homologue groups while emissions from secondary sources and long-range transport/ global background signatures are enriched in lower molecular weight congeners. Thus, this approach can be used to track potential emission sources. Principal Component Analysis (PCA) (XLSTAT Free Trial Version, https://www.xlstat.com) was applied to assess potential sources in Bursa (Fig. 4(A) and (B)). One-year average concentrations of PCBs congeners were composed as the active variables at different sampling sites. Loading plot of the PCA showed differences in the pattern of congeners at all sites. In Fig. 4(A), X and Y axis show F1 and F2 that explain 37.58\% and 31\% of the total variance, respectively. Low to middle chlorinated PCBs influenced the first component while second component was mainly influenced by the higher chlorinated PCBs congeners. Based on F1 and F2; MU, AGK and BTU are grouped together while KOID and HMT were at the border of this group. However, DOID, UUC and CAM were grouped separately. An analysis was performed to compare homologue profiles observed at sampling sites to different known sources such as transformers, landfill sites, capacitors, combustion etc. Since a detailed emission characterization of different PCBs sources in Turkey was not available, data reported for the U.K. by Conolly (2001) was used in this analysis. In the current study, variability of $3-\mathrm{Cl}$ to $7-\mathrm{Cl}$ homologue groups detected in samples is explained by 2 components. The first (F1) and second
(F2) factors accounted for $57.48 \%$ and $26.23 \%$ of the variance, respectively and the relationships among the variables are presented in the loading plot (Fig. 4(B)). Potential sources and grouping of the sampling sites displayed similarities. For example, KOID was grouped with cement plant and as stated above, a cement production plant is located in Kestel area. HMT grouped with landfill site. BTU, AGK, CAM and MU grouped with domestic wood and coal combustion, fragmentisers and capacitors. DOID grouped with coal combustion at industrial facilities and electric arc furnaces. There are various industrial facilities in DOID, especially in the textile industry which needs hot water for textile treatment, and coal burning is probably one of the methods to heat up the water. There is also a thriving automotive industry in DOID and iron/steel processing and applications in high temperatures are present in this area. Imamoğlu et al. (2010) reported that Aroclors $1242,1248,1254$ and 1260 were possibly used in Turkey before they were banned. Aroclor mixtures compositions reported by Frame et al. (1996) were also plotted on PCA analysis. Results of PCA plots highlighted a large variability of the $\mathrm{PCB}$ mixture in air, hence possible related sources, in Bursa area.

\subsection{Back trajectory and air masses}

Back-trajectory analysis was applied by using Hybrid-Single Particle Lagrangian Integrated Trajectory (HYSPLIT) model related to atmospheric transport and dispersion to evaluate whether origin of dominant air masses for sampling locations are similar or not. This model was developed by the National Oceanic and Atmospheric Administration's (NOAA) Air Resources Laboratory (ARL) (Draxler and Hess, 2005). Some input parameters such as receptor coordinates, meteorological data, starting height must be defined 

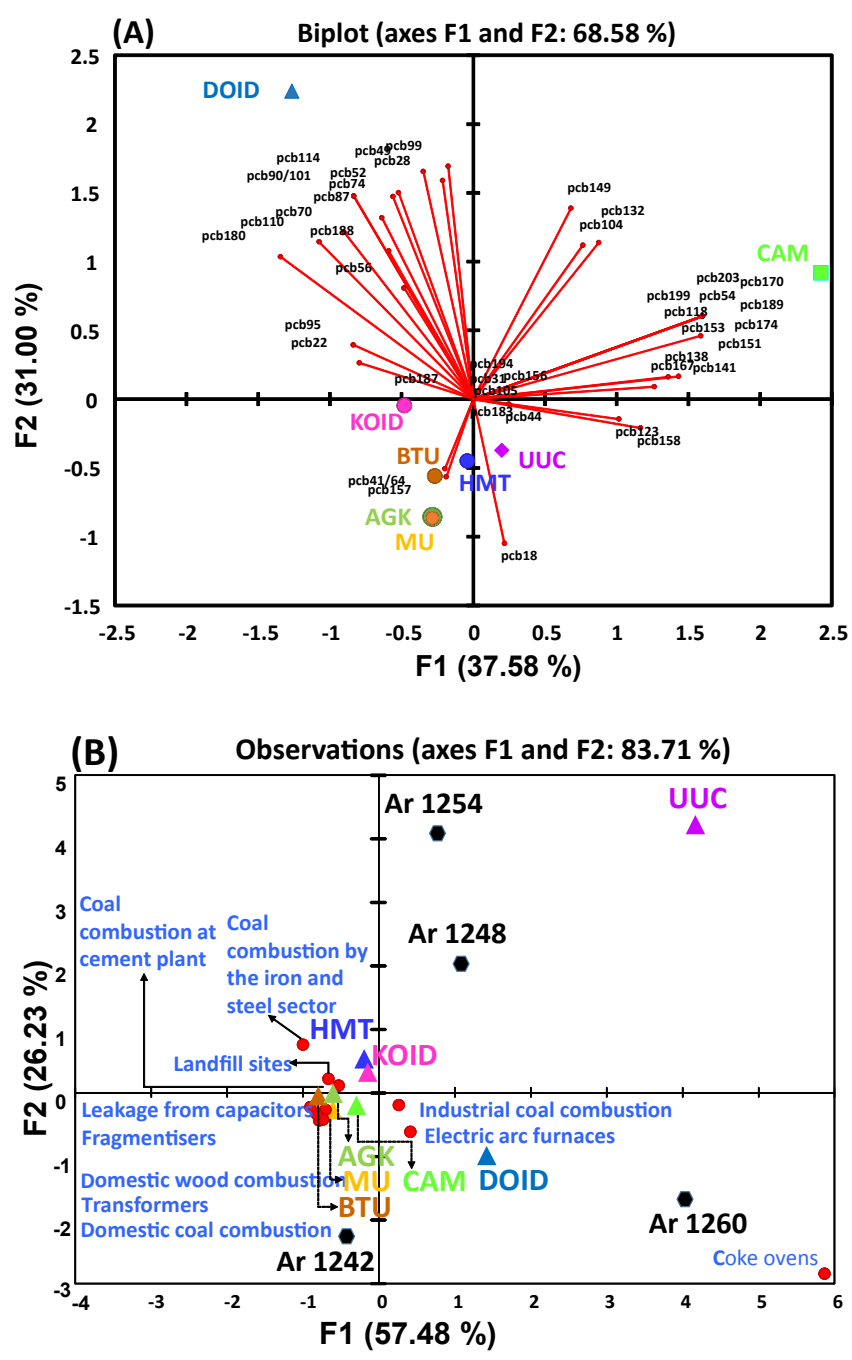

Fig. 4. Factor scores of principal component analysis (PCA) (A) applied to air measurements in sampling sites in Bursa (B) homologue groups in air from 8 sites of Bursa.

to the HYSPLIT model program in order to begin the back trajectory analysis. Use of multiple trajectories is the key point to increase sensitivity of the analysis. Meteorological datasets are supplied from global data assimilation system (GDAS) which includes all of the world. Trajectory starting height was chosen as $300 \mathrm{~m}$ as it is within the boundary layer also high enough to prevent effects of surface features. Cluster analysis was applied to merge trajectories which are near each other by their mean trajectory, and then the dominant wind directions during the sampling periods were obtained for each station, as shown in Figs. S1-S5 (Supplementary Material). The results of cluster analysis show that the dominant flow regimes for the sampling stations were similar during the same period, but variable for each sampling period. This result also supports that observed concentrations of PCBs are from "local emission sources" in Bursa rather than long range transport. Air masses travelled to the sampling stations from predominantly $\mathrm{N}$ NE between February-April 2014, June-August 2014, and August-October 2014 while the dominant flow regime was W-NW for April-June 2014, and S followed by W for October-December 2014. Cindoruk and Tasdemir (2007) conducted a study to determine concentration and gas/particle partitioning of PCBs at an industrial site in Bursa and they plotted back trajectories of the pollutants. They applied the Clausius-Clapeyron equation which yielded a low slope value indicating possible emissions from local and regional sources originating mainly from urban/industrial areas, landfill and waste incineration plant.

\subsection{Exposure and risk assessment}

Since people often prefer living in urban/industrialized areas due to economic reasons, it is important to assess the risk of chemicals to human health associated with exposure to these chemicals in such areas. EPA (2014) states that short- or mediumterm average exposure concentrations may be important for assessing acute or subchronic health effects, while long-term average concentrations are important for assessing the risk of chronic health effects such as cancer. In order to measure long-term average concentrations, passive sampling is a useful, convenient and cheap technique. As has been stated in previous studies, human exposure to POPs via inhalation is rather complicated and is controlled by many factors, such as gas-particle partitioning (Harrad et al., 2006; Wang et al., 2012) and exposure duration (Domingo et al., 2002; Zhang et al., 2009). Nevertheless, efforts to estimate cancer risk are important, particularly for people working outdoors, and such efforts must account for inhalation and dermal exposure. Overall, cancer risk is calculated in the current manuscript to give a preliminary evaluation of human exposure to chemicals of interest via inhalation in Bursa.

PCBs have been investigated for cancer risk factors due to their potential to act as direct and indirect carcinogens and their estrogenic and anti-estrogenic properties (Petrik et al., 2006). Malignant melanoma, non-Hodgkin lymphoma, and cancer of the breast, brain, and liver are linked with PCBs (ATSDR, 2000; IARC, 2016). They have been classified as carcinogenic to humans (Group 1) by the International Agency for Research on Cancer due to sufficient evidence of $\mathrm{PCB}$ carcinogenicity in humans/animals. Inhalation exposure due to $\Sigma_{43}$ PCBs was conducted by using the following equation (USEPA, 1997).

$C D I=\frac{C \times I R \times E D \times E F}{B W \times A T}$

where $C$ is the concentration of $\Sigma_{34} \mathrm{PCBs}\left(\mathrm{pg} / \mathrm{m}^{3}\right)$, IR is inhalation rate $\left(\mathrm{m}^{3} /\right.$ day), ED is exposure duration $(\mathrm{yr})$, EF is exposure frequency (days/yr), BW is body weight ( $\mathrm{kg}$ ), AT is averaging time which was assumed as lifetime and calculated as ED $\times 365$ day/yr, and CDI is inhalation chronic daily intake ( $\mathrm{pg} / \mathrm{kg} / \mathrm{day})$.

USEPA (2010) recommended toxic equivalency factors (TEFs) to convert the concentration of dioxin-like PCBs (DL PCBs) to dioxin (2,3,7,8-tetrachlorodibenzo-p-dioxin) toxic equivalence (TEQ). The concentration of targeted DL PCBs (PCB 105, 114, 118, 123, 156, 157, 167, and 189) (Supplementary Material Table S1) in this study were multiplied with the proposed TEF value of 0.00003. Yilmaz Civan (2010) collected time-activity budgets and demographic information from 197 participants in Bursa by administering a questionnaire. Distribution of IR (lognormal distribution; mean $=21.6 \mathrm{~m}^{3}$ / day, $\mathrm{SD}=8.85 \mathrm{~m}^{3} /$ day) and distribution of BW (beta distribution; alpha $=3.68$, beta $=3.05$, scale $=119$ ) were reported in the study. The mean \pm SD values of IR and BW taken from Yilmaz Civan (2010) were $21.6 \pm 8.85 \mathrm{~m}^{3} /$ day and $65.0 \pm 21.8 \mathrm{~kg}$, respectively. ED was taken as 70 years for lifetime exposure, and EF was 60 days/yr because samples were collected at intervals of two months.

Cancer risk related to $\Sigma_{34} \mathrm{PCBs}$ inhalation exposure was calculated for each sampling station/period by using the following equation (USEPA, 1996, 2005).

$R=C D I \times S F$ 
Table 2

The calculated mean inhalation exposure (CDI, pg/kg/day) and risk for $\Sigma_{43} \mathrm{PCBs}$.

\begin{tabular}{|c|c|c|c|c|c|c|c|c|c|c|}
\hline \multirow[t]{3}{*}{ Sampling station } & \multicolumn{10}{|c|}{ Sampling period } \\
\hline & \multicolumn{2}{|c|}{ February-April 2014} & \multicolumn{2}{|c|}{ April-June 2014} & \multicolumn{2}{|c|}{ June-August 2014} & \multicolumn{2}{|c|}{ August-October 2014} & \multicolumn{2}{|c|}{$\begin{array}{l}\text { October-December } \\
2014\end{array}$} \\
\hline & CDI & Risk & CDI & Risk & CDI & Risk & CDI & Risk & CDI & Risk \\
\hline AGK & 13.5 & $2.70 \times 10^{-8}$ & 1.24 & $2.48 \times 10^{-9}$ & 0.42 & $1.37 \times 10^{-9}$ & 0.21 & $3.16 \times 10^{-8}$ & 0.52 & $1.05 \times 10^{-9}$ \\
\hline BTU & 3.42 & $6.84 \times 10^{-9}$ & 1.16 & $2.32 \times 10^{-9}$ & 1.66 & $4.85 \times 10^{-9}$ & 1.07 & $2.13 \times 10^{-9}$ & 4.04 & $8.08 \times 10^{-9}$ \\
\hline CAM & 6.78 & $1.88 \times 10^{-8}$ & 2.47 & $4.94 \times 10^{-9}$ & 25.8 & $5.26 \times 10^{-8}$ & na & na & 2.41 & $4.82 \times 10^{-9}$ \\
\hline DOID & 67.4 & $1.35 \times 10^{-7}$ & 1.25 & $2.49 \times 10^{-9}$ & 2.23 & $4.46 \times 10^{-9}$ & 1.63 & $4.90 \times 10^{-9}$ & 2.42 & $4.84 \times 10^{-9}$ \\
\hline HMT & 35.9 & $7.17 \times 10^{-8}$ & 1.52 & $3.04 \times 10^{-9}$ & 0.95 & $2.83 \times 10^{-9}$ & 3.21 & $6.42 \times 10^{-9}$ & 1.72 & $3.45 \times 10^{-9}$ \\
\hline KOID & 6.26 & $1.34 \times 10^{-8}$ & 18.5 & $3.70 \times 10^{-8}$ & 17.4 & $3.47 \times 10^{-8}$ & 1.15 & $2.29 \times 10^{-9}$ & 3.15 & $6.30 \times 10^{-9}$ \\
\hline MU & 1.25 & $2.49 \times 10^{-9}$ & 1.94 & $3.87 \times 10^{-9}$ & 0.69 & $1.38 \times 10^{-9}$ & 1.27 & $2.55 \times 10^{-9}$ & 1.44 & $2.87 \times 10^{-9}$ \\
\hline UUC & 4.38 & $8.75 \times 10^{-9}$ & 2.26 & $5.48 \times 10^{-9}$ & 0.85 & $1.70 \times 10^{-9}$ & 2.70 & $5.41 \times 10^{-9}$ & 1.56 & $3.12 \times 10^{-9}$ \\
\hline
\end{tabular}

$R=R\left(\sum_{8} D L P C B s\right)+R\left(\sum_{35}\right.$ non $\left.-D L P C B s\right)$

where $\mathrm{R}$ is the cancer risk, SF is the slope factor of the PCB congeners $(\mathrm{pg} / \mathrm{kg} / \mathrm{day})^{-1}$. The SF values for nondioxin-like PCBs (non-DL PCBs) and DL PCBs were $2.0 \times 10^{-9}$ and $1.5 \times 10^{-4}(\mathrm{pg} / \mathrm{kg} / \mathrm{day})^{-1}$, respectively (USEPA, 2007).

The calculated mean CDIs and risks for different sampling station and period combinations were tabulated in Table 2 and Supplementary Material Table S2. The CDI reached to 35.9 and $67.4 \mathrm{pg} / \mathrm{kg} / \mathrm{day}$ in the period of February-April 2014 in HMT and DOSIB, while the minimum CDI was found in the period of August-October 2014 AGK $(0.21 \mathrm{pg} / \mathrm{kg} /$ day $)$. Lifetime cancer risks also ranged between $7.17 \times 10^{-8}$ (in HMT in the period of February-April 2014) and $1.35 \times 10^{-7}$ (in DOSIB in the period of February-April 2014). The acceptable carcinogenic risk is defined as one million chance of additional human cancer over a 70 year lifetime $\left(10^{-6}\right)$ by USEPA. Thus, all the calculated inhalation risk levels in this study are lower than the general acceptable risk level, indicating no serious adverse health effects. A similar result was recorded in the study conducted by Zhang et al. (2013) in the Yangtze River Delta. The air sampling of PCBs were carried out at 31 sites including three area groups: urban, urban-rural transition, and rural. The lifetime cancer risks due to PCBs exposure were calculated as $0.127 \times 10^{-6}, 0.129 \times 10^{-6}$, and $0.070 \times 10^{-6}$ for urban, urban-rural transition, and rural dwellers, respectively (Zhang et al., 2013). There is only one study conducted in Turkey, investigating the carcinogenic inhalation risk due to PCBs (Ugranli et al., 2016). The air samples were collected throughout a year (May 2003-April 2004) in a suburban site in Izmir. The overall (heating + non-heating period) 95th percentile carcinogenic risks for inhalation route was recorded as $2.49 \times 10^{-7}$ in the study, below the acceptable level, similar to findings of this study.

\section{Conclusions}

This study is the first effort to evaluate occurrence and distribution of PCBs concurrently in at multiple locations with different characteristics in Bursa using PAS samplers as previous researches were basically at single location and mostly by using high-vol samplers. The results show the important role and contribution of industrial sites as well as waste disposal site and urban areas as potential sources of PCBs. The spatial distribution of ambient air concentrations of PCBs in the current study indicates that the major sources of these chemical in Bursa region are industrial sites, waste disposal areas and urban areas. However, ambient air concentration values determined in Bursa metropolitan city were lower than the legal limits. PCB concentrations increased along a gradient from background to industrial areas by a factor of $1.7-11.4$. 3- to $5-\mathrm{Cl}$ homologue groups represented between $61 \%$ and $99 \%$ of total PCB amount in the atmosphere of Bursa. The PCB profile at all sampling sites was dominated by 4 -Cl PCBs (31.50-81.60\%). $\Sigma_{43}$ PCBs generally showed a uniform distribution in different sampling seasons. However, MU showed concentration pulses of $\Sigma_{43} \mathrm{PCBs}$ in February-April and in August-October whereas KOID and CAM showed a clear temperature dependent gradient of PCBs concentration which is probably result of air-surface exchange in local sources. Loading plot of potential sources and grouping of the sampling sites displayed similarities. Results of PCA plots highlighted a large variability of the PCB mixture in air, hence possible related sources, in Bursa area. Calculated inhalation risk levels in this study are lower than the general acceptable risk level, indicating no serious adverse health effects.

In addition to providing new data for POPs in Turkish atmospheric environment, the study has also helped to contribute importance of passive sampling studies to Turkish environmental scientists and policy makers and to demonstrate its applicability as an affordable and hands-on technique for concurrent monitoring POPs at multiple sites to assess effectiveness of chemicals management and control activities.

\section{Acknowledgements}

Dr. Henry Alegria was financially supported by Scientific and Technological Research Council of Turkey under the support programme "TUBITAK 2221-Fellowships for Visiting Scientists and Scientists on Sabbatical Leave" (grant number 21514107-221.018290) during his visit to laboratories of Bursa Technical University in 2014. Elif Gungormus, Tugba (Ugranli) Cicek and Halil Celik also received fellowship from TÜBITAK under grant number 112 Y315.

\section{Appendix A. Supplementary data}

Supplementary data related to this article can be found at http:// dx.doi.org/10.1016/j.chemosphere.2016.11.124.

\section{References}

Ampleman, M.D., Martinez, A., DeWall, J., Rawn, D.F.K., Hornbuckle, K.C., Thorne, P.S., 2015. Inhalation and dietary exposure to PCBs in urban and rural cohorts via congener-specific measurements. Environ. Sci. Technol. 49, 1156-1164.

Astoviza, M.J., Cappelletti, N., Bilos, C., Migoya, M.C., Colombo, J.C., 2016. Airborne PCB patterns and urban scale in the Suthern Rio de la Plata Basin, Argentina. Sci. Total Environ. 572, 16-22.

ATSDR, 2000. Toxicological Profile for Polychlorinated Biphenyls. U.S. Department of Health and Human Services, Public Health Service, Atlanta, GA.

Aydin, Y.M., Kara, M., Dumanoglu, Y., Odabasi, M., Elbir, T., 2014. Source apportionment of polycyclic aromatic hydrocarbons (PAHs) and polychlorinated biphenyls (PCBs) in ambient air of an industrial region in Turkey. Atmos. Environ. 
97, 271-285.

Backe, C., Larsson, P., Okla, L., 2000. Polychlorinated biphenyls in the air of southern Sweden spatial and temporal variation. Atmos. Environ. 34, 1481-1486.

Baek, S.Y., Choi, S.D., Lee, S.J., Chang, Y.S., 2008. Assessment of the spatial distribution of coplanar PCBs, PCNs, and PBDEs in a multi-industry region of South Korea using passive air samplers. Environ. Sci. Technol. 42, 7336-7340.

Bartkow, M.E., Hawker, D.W., Kennedy, K.E., Müller, J.F., 2004. Characterizing uptake kinetics of PAHs from the air using polyethylene-based passive air samplers of multiple surface area-to-volume ratios. Environ. Sci. Technol. 38, 2701-2706.

Birgul, A., Tasdemir, Y., 2011. Seasonal atmospheric deposition variations of polychlorinated biphenyls (PCBs) and comparison of some deposition sampling techniques. Environ. Sci. Pollut. Res. 18, 396-406.

Birgul, A., Tasdemir, Y., 2012. Determination of the sampler type and rainfall effect on the deposition fluxes of the polychlorinated bipheniyls. Sci. World J. 2012 http://dx.doi.org/10.1100/2012/798020. Article ID 798020, 10 pages.

Bozlaker, A., Odabasi, M., Muezzinoglu, A., 2008. Dry deposition and soil-air gas exchange of polychlorinated biphenyls (PCBS) in an industrial area. Environ. Pollut. 156, 784-793.

Breivik, K., Sweetman, A., Pacyna, J.M., Jones, K.C., 2007. Towards a global historical emission inventory for selected PCB congeners - a mass balance approach: 3 . An update. Sci. Total Environ. 377 (2-3), 296.

Chiu, A., Beauber, J., Chiu, J., Chan, L., Gerstenberger, S., 2004. Epidemiologic studies of PCB congener profiles in North American fish consuming populations. J. Environ. Sci. Health 22 (Part C), 13-36.

Cindoruk, S.S., Tasdemir, Y., 2007. Characterization of gas/particle concentrations and partitioning of polychlorinated biphenyls (PCBs) measured in an urban site of Turkey. Environ. Pollut. 148 (1), 325-333.

Conolly, C., 2001. Speciation of the UK Polychlorinated Biphenyl Emission Inventory, A Report Produced for Department for Environment, Food and Rural Affairs, the National Assembly for Wales, the Scottish Executive and the Department of the Environment in Northern Ireland. AEAT/r/env/0001.

Currado, G.M., Harrad, S., 1998. Comparison of polychlorinated biphenyl concentrations in indoor and outdoor air and the potential significance of inhalation as a human exposure pathway. Environ. Sci. Technol. 32 (20), 3043-3047.

DeCaprio, A.P., Johnson, G.W., Tarbell, A.M., Carpenter, D.O., Chiarenzelli, J.R., Morse, G.S., Santiago-Rivera, A.L., Schymura, M.J., 2005. Polychlorinated biphenyl $(\mathrm{PCB})$ exposure assessment by multivariate statistical analysis of serum congener profiles in an adult Native American population. Environ. Res. 98, 284-302.

Domingo, J.L., Agramunt, M.C., Nadal, M., Schuhmacher, M., Corbella, J., 2002. Health risk assessment of $\mathrm{PCDD} / \mathrm{PCDF}$ exposure for the population living in the vicinity of a municipal waste incinerator. Arch. Environ. Contam. Toxicol. 43, 461-465.

Draxler, R.R., Hess, G.D., 2005. HYSPLIT 4 USER's Guide, Technical Memorandum. NOAA, Washington, DC.

EEA (European Environment Agency), 2005. Sources of Polychlorinated Biphenyls Emissions, EMEP/CORINAIR Guidebook, BPCB_A-1 available at: www.eea. europa.eu/publications/EMEPCORINAIR5/Sources_of_PCB_emissions.pdf. accessed on 03 November 2016.

EPA (United States Environmental protection Agency), 2014. Passive Samplers for Investigations of Air Quality: Method Description, Implementation, and Comparison to Alternative Sampling Methods, Engineering Issue, p. 43 available at: https://nepis.epa.gov/Exe/ZyPDF.cgi/P100MK4Z.PDF?Dockey=P100MK4Z.PDF. accessed on 05 November 2016.

Erickson, M.D., 2001. PCB properties, uses, occurrence, and regulatory history. In: Robertson, L.W., Hansen, L.G. (Eds.), PCBs, Recent Advances in Environmental Toxicology and Health Effects. The University Press of Kentucky, Lexington, KY, p. 11.

Esen, F., 2013. Development of a passive sampling device using polyurethane foam (PUF) to measure polychlorinated biphenyls (PCBs) and organochlorine pesticides (OCPs) near landfills. Environ. Forensics 14, 1-8.

Frame, G.M., Wagner, R.E., Carnahan, J.C., Brown, J.F., May, R.J., Smullen, L.A., Bedard, D.L., 1996. Comprehensive quantitative, congener-specific analyses of eight Aroclors and complete PCB congener assignments on DB-1 capillary GC columns. Chemosphere 33 (4), 603-623.

Gaga, E.O., Ari, A., Dogeroglu, T., Cakirca, E.E., Machin, N.E., 2012. Atmospheric polycyclic aromatic hydrocarbons in an industrialized city, Kocaeli, Turkey: study of seasonal variations, influence of meteorological parameters and health risk estimation. J. Environ. Monit. 14, 2219-2229.

Gouin, T., Harner, T., Blanchard, P., Mackay, D., 2005. Passive and active air samplers as complementary methods for investigating persistent organic pollutants in the Great Lakes Basin. Environ. Sci. Technol. 39, 9115-9122.

Harner, T., 2016. v1 3 Template for Calculating PUF and SIP Disk Sample Air Volumes, March 11.

Harner, T., Shoeib, M., Diamond, M.L., Stern, G.A., Rosenberg, B., 2004. Using passive air samplers to assess urban-rural trends for persistent organic pollutants. 1. Polychlorinated biphenyls and organochlorine pesticides. Environ. Sci. Technol. 38, 4474-4483.

Harrad, S., Hazrati, S., Ibarra, C., 2006. Concentrations of polychlorinated biphenyls in indoor air and polybrominated diphenyl ethers in indoor air and dust in Birmingham, United Kingdom: implications for human exposure. Environ. Sci. Technol. 40, 4633-4638.

Hogarh, J.N., Seike, N., Kobara, Y., Habib, A., Namd, J.J., Lee, J.S., Li, Q., Liu, X., Li, J., Zhang, G., Masunaga, S., 2012. Passive air monitoring of PCBs and PCNs across East Asia: a com- prehensive congener evaluation for source characterization. Chemosphere 86, 718-726.
Humphrey, H.E.B., 1983. Population studies of PCBs in Michigan residents. In: D'Itri, F.M., Kamrin, M. (Eds.), PCBs: Human and Environmental Studies. Butterworth, Boston, pp. 299-310.

IARC, 2016. Polychlorinated Biphenyls and Polybrominated Biphenyls, vol. 107. International Agency for Research on Cancer Monographs on the evaluation of Carcinogenic Risks to Humans, Lyon, France, pp. 439-440.

Imamoğlu, I., Akduman, N., Demircioğlu, F., Gedik, K., 2010. Türkiye'nin Poliklorlu Bifeniller Kaynaklı Kirlilik Durumunun Belirlenmesi ve Bu Kirleticilerin Akıbetinin İncelenmesi. TÜBiTAK Career Program Project Number: 104 I126 Final Report, June 2010, Ankara.

Jaward, F.M., Farrar, N.J., Harner, T., Sweetman, A.J., Jones, K.C., 2004. Passive air sampling of PCBs, PBDEs, and organochlorine pesticides across Europe. Environ. Sci. Technol. 38, 34-41.

Jaward, F.M., Zhang, G., Nam, J.J., Sweetman, A.J., Obbard, J.P., Kobara, Y., Jones, K.C., 2005. Passive air sampling of polychlorinated biphenyls, organochlorine compounds, and polybrominated diphenyl ethers across Asia. Environ. Sci. Technol. 39, 8638-8645.

Kaya, E., Dumanoglu, Y., Kara, M., Altiok, H., Bayram, A., Elbir, T., Odabasi, M., 2012. Spatial and temporal variation and air-soil exchange of atmospheric PAHs and PCBs in an industrial region. Atmos. Pollut. Res. 3, 435-449.

Kim, M.J., Marchand, P., Henegar, C., Antignac, J.P., Alili, R., Poitou, C., Bouillot, J.-L., Basdevant, A., Le Bizec, B., Barouki, R., Clement, K., 2011. Fate and complex pathogenic effects of dioxins and polychlorinated biphenyls in obese subjects before and after drastic weight loss. Environ. Health Perspect. 119, 377-383.

Klánová, J., Čupr, P., Holoubek, I., Borůvková, J., Přibylová, P., Kareš, R., Kohoutek, J., Dvorská, A., Tomšej, T., Ocelka, T., 2008. Application of Passive Sampler for Monitoring of POPs in Ambient Air - Part VI: Pilot Study for Development of the Monitoring Network in the African Continent. RECETOX MU, Brno. ISBN 978980-210-4739-4736.

Lee, D.H., Lee, I.K., Porta, M., Steffes, M., Jacobs Jr., D.R., 2007. Relationship between serum concentrations of persistent organic pollutants and the prevalence of metabolic syndrome among non-diabetic adults: results from the National Health and Nutrition Examination Survey 1999-2002. Diabetologia 50 (9), 1841-1851.

MoEU (Ministry of Environment and Urbanisation), 2016. Stockholm Convention. General Directorate of Environmental Management, Chemicals Management Department. http://www.csb.gov.tr/projeler/chemicals/index.php? Sayfa $=$ sayfa\&Tur=webmenu\&Id=14824. accessed on 19 August 2016.

Motelay-Massei, A., Harner, T., Shoeib, M., Diamond, M., Stern, G., Rosenberg, B. 2005. Using passive air samplers to assess urban-rural trends for persisten organic pollutants and polycyclic aromatic hydrocarbons. 2. Seasonal trends for PAHs, PCBs, and organochlorine pesticides. Environ. Sci. Technol. 39, 5763-5773.

Mulder, M.D., Heil, A., Kukucka, P., Kuta, J., Pribylová, P., Prokeš, R., Lammel, G., 2015 Long-range atmospheric transport of PAHs, PCBs, OCPs and PBDEs to the centra and eastern Mediterranean 2010 changes of PCB and PBDE congener patterns in summer 2010. Atmos. Environ. 111, 51-59.

NIP (National Implementation Plan), 2015. National Implementation Plan of Persistent Organic Pollutants (POPs) Management in Turkey. Ministry of Environment and Urbnisation. http://www.csb.gov.tr/db/chemicals/editordosya/2_\% 20NIP\%20Text_Draft_En.pdf. accessed on 19 August 2016.

Norström, K., Czub, G., McLachlan, M.S., Hu, D., Thorne, P.S., Hornbuckle, K.C., 2010 External exposure and bioaccumulation of PCBs in humans living in a contaminated urban environment. Environ. Int. 36 (8), 855-861.

Odabasi, M., Falay, E.O., Tuna, G., Altiok, H., Kara, M., Dumanoglu, Y., Bayram, A Tolunay, D., Elbir, T., 2015. Biomonitoring the spatial and historical variations of persistent organic pollutants (POPs9 in an Industrial Region. Environ. Sci. Technol. 49, 2105-2114.

Odabasi, M., Dumanoglu, Y., Falay, E.O., Tuna, G., Altiok, H., Kara, M., Bayram, A. Tolunay, D., Elbir, T., 2016. Investigation of spatial distributions and sources of persistent organic pollutants (POPs) in a heavily polluted industrial region using tree components. Chemosphere 160, 114-125.

Official Gazzette, 2013. Turkish Legislation on Control of Air Pollution Originating from Industrial Activities, Official Gazette Number: 28712, Date: 19.07.2013.

Parnis, J.M., Eng, A., Mackay, D., Harner, T., 2016. Characterizing PUF disk passive air samplers for alkyl-substituted PAHs: measured and modelled PUF-AIR partition coeffi- cients with COSMO-RS. Chemosphere 145, 360-364.

Persoon, C., Peters, T.M., Kumar, N., Hornbuckle, K.C., 2010. Spatial distribution of airborne polychlorinated biphenyls in Cleveland, Ohio and Chicago. Ill. Env. Sci. Technol. 44, 2797-2802.

Petrik, J., Drobna, B., Pavuk, M., Jursa, S., Wimmerova, S., Chovancova, J., 2006 Serum PCBs and organochlorine pesticides in Slovakia: age, gender, and residence as determinants of organochlorine concentrations. Chemosphere 65 (3), 410-418.

Pozo, K., Harner, T., Shoeib, M., Urrutia, R., Barra, R., Parra, O., Focardi, S., 2004. Passive-sampler derived air concentrations of persistent organic pollutants on a north-south transect in Chile. Environ. Sci. Technol. 38, 6529-6537.

Pozo, K., Harner, T., Wania, F., Muir, D.C.G., Jones, K.C., Barrie, L.A., 2006. Toward a global network for persistent organic pollutants in air: results from the GAPS study. Environ. Sci. Technol. 40, 4867-4873.

Pozo, K., Harner, T., Lee, S.C., Wania, F., Muir, D.C.G., Jones, K.C., 2009. Seasonally resolved concentrations of persistent organic pollutants in the global atmosphere from the first year of the GAPS study. Environ. Sci. Technol. 43, 796-803.

Pozo, K., Harner, T., Lee, S.C., Sinha, R.K., Sengupta, B., Loewen, M. Geethalakshmi, V., Kannan, K., Volpi, V., 2011. Assessing seasonal and spatial 
trends of persistent organic pollutants (POPs) in Indian agricultural regions using PUF disk passive air samplers. Environ. Pollut. 159, 646-653.

Pozo, K., Harner, T., Rudolph, A., Oyola, G., Estellano, V.H., Ahumada-Rudolph, R., Garrido, M., Pozo, K., Mabilia, R., Focardi, S., 2012. Survey of persistent organic pollutants (POPs) and polycyclic aromatic hydrrocarbons (PAHs) in the atmosphere of rural, urban and industrial areas of Concepcion, Chile, using passive air samplers. Atmos. Pollut. Res. 3, 426-434.

Salihoglu, G., Tasdemir, Y., 2009. Prediction of the PCB pollution in the soils of Bursa an industrial city in Turkey. J. Hazard. Mater. 164, 1523-1531.

Shoeib, M., Harner, T., 2002. Characterization and comparison of three passive air samplers for persistent organic pollutants. Environ. Sci. Technol. 36, 4142-4151.

Tasdemir, Y., Salihoglu, G., Salihoglu, N.K., Birgul, A., 2012. Air-soil exchange of PCBs: seasonal variations in levels and fluxes with influence of equilibrium conditions. Environ. Pollut. 169, 90-97.

Ugranli, T., Gungormus, E., Kavcar, P., Demircioglu, E., Odabasi, M., Sofuoglu, S.C., Lammel, G., Sofuoglu, A., 2016. POPs in a major conurbation in Turkey: ambient air concentrations, seasonal variation, inhalation and dermal exposure, and associated carcinogenic risks. Environ. Sci. Pollut. Res. http://dx.doi.org/10.1007/ s11356-016-7350-5.

USEPA, 1996. PCBs: Cancer Dose-response Assessment and Application to Environmental Mixtures. US Environmental Protection Agency, Washington, DC.

USEPA, 1997. Exposure Factors Handbook, EPA/600/P-95/002Fa. US Environmenta Protection Agency, Office of Research and Development National Center for Environmental Assessment, Washington, DC.

USEPA, 2005. Guidelines for Carcinogen Risk Assessment. Risk Assessment Forum, US Environmental Protection Agency, Washington, DC.

USEPA, 2007. Slope Factors (SF) for Carcinogens. US Environmental Protection Agency, Washington, DC.

USEPA, 2010. Recommended Toxicity Equivalence Factors (TEFs) for Human Health Risk Assessments of 2,3,7,8-Tetrachlorodibenzo-p-dioxin and Dioxin-like Compounds. US Environmental Protection Agency, Washington, DC.
Wang, P., Zhang, Q., Wang, Y., Wang, T., Li, X., Li, Y., Ding, L., Jiang, G., 2009. Altitude dependence of polychlorinated biphenyls (PCBs) and polybrominated dipheny ethers (PBDEs) in surface soil from Tibetan Plateau, China. Chemosphere 76, $1498-1504$

Wang, X.P., Gong, P., Yao, T.D., Jones, K.C., 2010. Passive air sampling of organochlorine polychlorinated biphenyls, and polybrominated diphenyl ethers across the Tibetan plateau. Environ. Sci. Technol. 44, 2988-2993.

Wang, J., Chen, S., Tian, M., Zheng, X., Gonzales, L., Ohura, T., Mai, B., Simonich, S.L.M., 2012. Inhalation cancer risk associated with exposure to complex polycyclic aromatic hydrocarbon mixtures in an electronic waste and urban area in South China. Environ. Sci. Technol. 46, 9745-9752.

Wania, F., Shen, L., Lei, Y.D., Teixera, C., Muir, D.C.G., 2003. Development and calibration of a resin based passive sampling system for monitoring persistent organic pollutants in the atmosphere. Environ. Sci. Technol. 37, 1352-1359.

Xiao, H., Hung, H., Harner, T., Lei, Y., Wania, F., 2008. Field testing a flow-through sampler for semivolatile organic compounds in air. Environ. Sci. Technol. 42, 2970-2975.

Yilmaz Civan, M., 2010. Spatial Distribution of Organic Pollutants in Bursa Atmosphere: Seasonality and Health Effects. Environmental Engineering Department, Middle East Technical University (Thesis).

Zhang, Z., Liu, L.Y., Li, Y.F., Wang, D.G., Jia, H.L., Harner, T., Sverko, E., Wan, X.N., Xu, D.D., Ren, N.Q., Ma, J.M., Pozo, K., 2008. Analysis of polychlorinated biphenyls in concurrently sampled Chinese air and surface soil. Environ. Sci. Technol. 42, 6514-6518.

Zhang, Y., Tao, S., Shen, H., Ma, J., 2009. Inhalation exposure to ambient polycyclic aromatic hydrocarbons and lung cancer risk of Chinese population. PNAS 106 21063-21067.

Zhang, L., Dong, L., Yang, W., Zhou, L., Shi, S., Zhang, X., Niu, S., Li, L., Wu, Z., Huang, Y., 2013. Passive air sampling of organochlorine pesticides and polychlorinated biphenyls in the Yangtze River Delta, China: concentrations, distributions, and cancer risk assessment. Environ. Pollut. 181, 159-166. 